\title{
Algoritma K-Means pada Pengelompokan Pembelajaran Tatap Muka Terbatas Sesudah Vaksinasi COVID-19
}

\author{
Lili Kartikawati ${ }^{1}$, Kusrini ${ }^{2}$, Emha Taufiq Luthfi $^{3}$ \\ Teknik Informatika \\ Amikom Yogyakarta \\ Yogyakarta, Indonesia \\ e-mail: ${ }^{1}$ lili_kartikawati@students.amikom.ac.id, ${ }^{2}$ kusrini@amikom.ac.id, ${ }^{3}$ emha_tl@yahoo.com \\ Diajukan: 27 Juni 2021; Direvisi: 21 November 2021; Diterima: 26 November 2021
}

\begin{abstract}
Abstrak
Pandemi COVID-19 menimbulkan potensi dampak sosial yang kurang baik, peranan sekolah dalam proses belajar mengajar tidak terlihat. Akses dan kualitas pembelajaran jarak jauh berbanding lurus dengan capaian belajar peserta didik. Capaian hasil belajar peserta didik menunjukkan tingkat kualitas pembelajaran yang telah dilakukan. Peserta didik yang terkendala dalam mencapai hasil belajar maka dibutuhkan langkah perbaikan proses belajar di antaranya melalui pembelajaran tatap muka terbatas. Pembelajaran tatap muka terbatas wajib menaati prosedur kesehatan, di antaranya pembatasan jumlah maksimal peserta didik dalam satu Rombel. Pengelompokan peserta didik dipilih sebagai solusi pembatasan jumlah peserta didik dalam Rombel. Metode eksperimen penelitian ini diterapkan pada hasil capaian belajar selama tengah semester genap 2020/2021 peserta didik X Usaha Perjalanan Wisata 1 di SMK Negeri 4 Yogyakarta. Pengelompokan dan pembuktian kualitas pengelompokan algoritma K-Means menggunakan metode silhouette coefficient serta rumus euclidean distance untuk mengukur jarak di antara dokumennya. Hal yang membedakan dengan penelitian clustering sebelumnya di antaranya dilakukan pengukuran kualitas peng-cluster-an dan melakukan penggalian lebih dalam pada pola-pola baru hasil peng-cluster-an yang terbentuk sehingga didapatkan pengetahuan baru. Kualitas clustering menghasilkan nilai Si=0,8313 yang berarti memiliki karakteristik struktur kuat dan menampilkan pengetahuan baru berupa kelompok rumpun mata pelajaran yang menginformasikan tingkatan daya serap peserta didik terhadap mata pelajaran.
\end{abstract}

Kata kunci: Algoritma K-Means, Kualitas clustering, Data mining, Pembelajaran tatap muka terbatas.

\begin{abstract}
The COVID-19 pandemic raises the potential for adverse social impacts, the role of schools in the teaching and learning process is not visible. Access and quality of distance learning is directly proportional to the learning achievement of students. The achievement of student learning outcomes shows the level of quality of learning that has been carried out. Students who are constrained in achieving learning outcomes are required to take steps to improve learning, including through limited face-to-face learning. Limited face-to-face learning must comply with health procedures, including the maximum number of students in one group. The grouping of students was chosen as a solution to the number of students in the group. This research experimental method was applied to the results of learning outcomes during the even semester of 2020/2021 for students of X Business Travel 1 at SMK Negeri 4 Yogyakarta. Grouping and proving the quality of the K-Means clustering algorithm uses the silhouette method and the Euclidean distance formula to measure the distance between the documents. The things that distinguish it from previous clustering studies include measuring the quality of clustering and making deeper observations on new patterns of clustering results that are formed so that new knowledge is obtained. Clustering produces a value of $\mathrm{Si}=0.8313$ which means it has strong characteristics and displays new knowledge in the form of groups of subjects with the level of student assessment of the subject.
\end{abstract}

Keywords: K-Means Algorithm, Clustering quality, Data mining, Limited face-to-face learning.

\section{Pendahuluan}

Pandemi COVID-19 setahun ini telah menimbulkan potensi dampak sosial negatif yang berkepanjangan, banyak orang tua yang tidak melihat peranan sekolah dalam proses belajar mengajar [1]. 
Akses dan kualitas pembelajaran jarak jauh berbanding lurus dengan capaian belajar peserta didik. Peserta didik yang diberlakukan pembelajaran tatap muka terbatas sesudah pelaksanaan vaksinasi COVID-19 ini diterapkan teknik pengelompokan algoritma $\mathrm{K}$-Means. Pengelompokan berdasarkan hasil capaian belajar selama tengah semester genap 2020/2021.

Pengelompokan model pembelajaran dan rumpun mata pelajaran menerapkan algoritma $\mathrm{K}$-Means. Algoritma non hierarki yang memanfaatkan metode data clustering untuk memartisi data ke dalam kelompok sehingga menyuguhkan data dalam kelompok yang memiliki karakteristik sama. Penelitian sebelumnya yang menjadi rujukan di antaranya adalah pembuatan aplikasi berbasis web untuk memilih media promosi yang terbaik dengan menerapkan metode K-Means Clustering [2], pembuatan aplikasi desktop untuk memberikan solusi sebagai refleksi terhadap sistem pembelajaran online yang berjalan berdasarkan efektivitas pembelajaran online dengan mempertimbangkan fasilitas belajar online, kesiapan dan kemampuan siswa beradaptasi dalam pembelajaran di kenormalan baru pandemi COVID-19 [3], penerapan algoritma $\mathrm{K}$-Mean dalam menentukan tingkat kepuasan pembelajaran online pada masa pandemi COVID-19 berdasarkan jawaban "setuju” atau "tidak"-nya dari jawaban responden terhadap instrumen kuesioner online [4], penerapan metode clustering dengan algoritma K-Means tindak kejahatan pencurian di kabupaten asahan [5], clustering kinerja dosen berdasarkan kualitas pelaksanaan Tridharma (Pendidikan, pengabdian kepada masyarakat, dan kegiatan penunjang lainnya) untuk mengontrol keseimbangan kinerja dosen [6], memetakan kelompok belajar siswa berdasarkan nilai rapor pada semester I sampai dengan IV dalam 3 kelompok yaitu sangat berprestasi, berprestasi, dan kurang berprestasi menggunakan metode Clustering K-Means [7]. Sebagian besar penelitian tersebut memanfaatkan angket, responden, jajak pendapat untuk dijadikan sumber data pengelompokan, belum memaksimalkan konsep data mining untuk menemukan pengetahuan baru dari pola-pola baru hasil pengelompokan dan sebagian besar belum melakukan pengukuran kualitas hasil pengelompokannya.

Hal yang membedakan dengan penelitian clustering algoritma K-Means sebelumnya adalah penelitian ini melakukan pengukuran kualitas pengelompokan dari sumber data fisik yang bersifat jelas dan adaptif serta melakukan penggalian lebih dalam pada pola-pola baru hasil pengelompokan yang terbentuk sebagai jalan untuk menemukan pengetahuan baru. Berdasarkan kebutuhan pengelompokan model pembelajaran dan sumber data nilai capaian hasil belajar peserta didik selama tengah semester genap 2020/2021 di SMK Negeri 4 Yogyakarta maka perlu dilakukan penelitian untuk mendapatkan pengelompokan menggunakan teknik clustering dengan algoritma K-Means yang berkualitas dan untuk mendapatkan pengetahuan baru dari proses data mining melalui pola-pola baru yang ditemukan. Pengelompokan yang dilakukan pada penelitian ini menghasilkan nilai $S_{i}=0,8313$, masuk kategori struktur kuat. Struktur kuat mengandung arti bahwa jarak di antara objek dalam satu kelompok berdekatan (kelompok menunjukkan karakteristik objek yang sama) dan jarak objek di antara kelompok berpotensi kecil berada pada lebih dari satu kelompok (struktur baik). Penggalian pola-pola baru hasil pengelompokan dua kelompok model pembelajaran, mampu menampilkan pengetahuan baru berupa kelompok rumpun mata pelajaran yang menginformasikan persentase jumlah peserta didik tidak terkendala dalam proses pembelajaran di masing-masing mata pelajaran sebagai tingkat daya serap, di mana tingkat daya serap yang terbentuk terbagi menjadi 4 kelompok yaitu daya serap tinggi, daya serap standar, daya serap rendah dan daya serap kurang.

\section{Metode Penelitian}

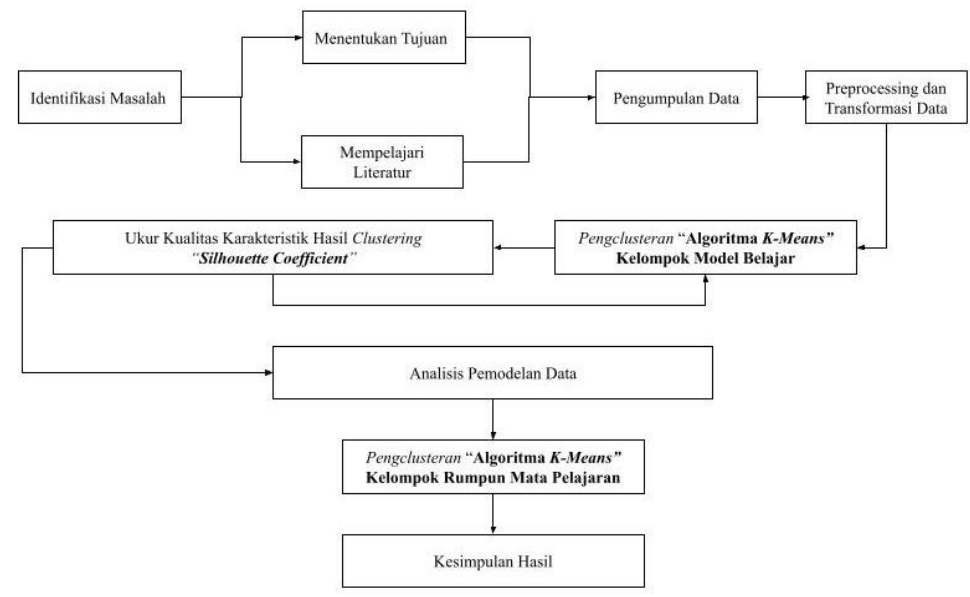

Gambar 1. Alur Penelitian. 
Alur penelitian menggunakan metode eksperimen yang dapat dibaca pada Gambar 1, dimulai dari mengidentifikasi permasalahan sampai dengan menghasilkan kesimpulan. Pandemi COVID-19 menimbulkan peranan sekolah dalam proses belajar mengajar tidak terlihat. Capaian hasil belajar peserta didik menunjukkan tingkat kualitas proses pembelajaran yang telah dilakukan. Peserta didik yang terkendala dalam mencapai hasil belajar maka dibutuhkan langkah perbaikan proses belajar di antaranya melalui pembelajaran tatap muka terbatas. Pembelajaran tatap muka terbatas wajib menaati prosedur kesehatan, di antaranya pembatasan jumlah maksimal peserta didik dalam satu Rombongan Belajar (Rombel). Pengelompokan peserta didik dipilih sebagai solusi pembatasan jumlah peserta didik dalam Rombel.

Penelitian sebelumnya yang menjadi rujukan sebagian besar memanfaatkan angket, responden, jejak pendapat untuk dijadikan sumber data pengelompokan [2]-[4], [6]. Pengelompokan menggunakan algoritma K-Means sebagai solusi pengelompokan yang banyak digunakan [5], [7]. Pengelompokan yang dilakukan belum melakukan pengukuran kualitas hasil dan belum memaksimalkan konsep data mining untuk menemukan pengetahuan baru dari pola-pola baru hasil pengelompokannya.

Data hasil capaian belajar selama tengah semester genap 2020/2021 peserta didik X Usaha Perjalanan Wisata 1 di SMK Negeri 4 Yogyakarta dilakukan proses preprocessing. Preprocessing dengan melakukan pemilihan field yang dibutuhkan, membersihkan data yang tidak terpakai, melakukan pengecekan konsistensi data. Transformasi data dilakukan untuk mendapatkan nilai rerata permata pelajaran. Data-data yang memiliki tingkat variasi yang kecil dimasukkan dalam 1 kelompok sehingga dalam satu kelompok dapat menunjukkan kemiripan karakteristik yang dimiliki [8]. Pengelompokan model pembelajaran dilakukan menggunakan algoritma $K$-Means dengan jumlah kelompok kebutuhan sebanyak dua yaitu pembelajaran tatap muka terbatas (PTMT) dan pembelajaran jarak jauh (PJJ). Persamaan 1 digunakan untuk menentukan nilai titik tengah (centroid) sesuai dengan jumlah kelompok yang telah ditentukan.

$$
\mathrm{C}_{i}=\operatorname{Min}+\frac{(i-1) *(\operatorname{Max}-\operatorname{Min})}{n}+\frac{(\operatorname{Max}-\operatorname{Min})}{(2 * \mathrm{n})}
$$

Penentuan titik tengah atau nilai centroid dari kelas ke-i disimbolkan dengan $\mathrm{C} i$ dipengaruhi oleh nilai terkecil dari data kelas kontinu yang ditampung dalam variabel Min dan juga nilai terbesar dari data kelas diskret dengan penampungan dalam variabel Max dan variabel $n$ sebagai jumlah kelas diskretnya.

Langkah selanjutnya setelah diketahui centroid masing-masing kelompok yang dibutuhkan maka dilakukan perhitungan jarak data ke pusat kelompok menggunakan Persamaan 2 sehingga pengalokasian masing-masing data ke pusat kelompok terdekat dapat dilakukan.

$$
\mathrm{Be}=\sqrt{\left(\mathrm{O}_{i}-C_{i}\right)^{2}+\left(\mathrm{O}_{\mathrm{j}}-C_{j}\right)^{2}}
$$

Jarak data ke pusat kelompok (Be) dipengaruhi oleh data record ke- $i(\mathrm{O} i)$, data record ke-j $(\mathrm{O} j)$, dan data centroid ke-i $(C i)$ dan data centroid ke-j $(C j)$ dikenal dengan rumus euclidean distance [9]. Setelah dilakukan pelabelan terhadap data maka akan dilakukan akurasi centroid dengan menggunakan Persamaan 3 untuk membuktikan bahwa centroid yang telah ditentukan memiliki struktur yang kuat (tidak bergeser lagi).

$$
\mathrm{C}_{i}=\frac{\left(\mathrm{O}_{i}+\ldots+\mathrm{O}_{\mathrm{n}}\right)}{\sum O}
$$

Centroid baru dipengaruhi oleh nilai data record ke- $i(0 i)$, nilai data record ke- $n(0 n)$ dan jumlah data record $\left(\sum 0\right)$.

Penerapan alokasi pusat kelompok yang baru akan dilakukan apabila pusat kelompok masih mengalami perubahan. Proses iterasi akan berjalan terus sampai dengan ditemukan pusat cluster yang tetap. Hasil pengelompokan yang telah didapatkan akan dilakukan pengujian kualitas karakteristik pengelompokan menggunakan silhouette coefficient. Gabungan dari dua metode yaitu metode cohesion yang berperan untuk mengukur kedekatan relasi antar objek dalam sebuah kelompok dan metode separation yang memiliki peran untuk mengukur jarak sebuah kelompok dengan kelompok lain. Pengukuran kualitas pengelompokan dengan silhouette coefficient dimulai dengan menggunakan Persamaan 4 untuk menghitung rata-rata jarak objek dengan semua objek lain yang berada di dalam satu kelompok, dilanjutkan dengan memanfaatkan Persamaan 5 untuk menghitung rata-rata jarak objek dengan 
semua objek lain yang berada pada kelompok lain, kemudian mengambil nilai paling minimum, diakhiri dengan penggunaan Persamaan 6 untuk menghitung nilai silhouette coefficient. Penafsiran nilai hasil perhitungan kualitas pengelompokan dengan metode silhouette coefficient adalah nilai Si berada di antara -1 sampai dengan 1, nilai Si mendekati 1 dikategorikan sebagai pengelompokan dengan kualitas karakteristik yang lebih baik sedangkan pada nilai Si mendekati -1 diartikan sebagai pengelompokan yang kurang berkualitas [10].

$$
\begin{gathered}
a(i)=\frac{1}{|A|} \sum_{j \in} d(i, j) \\
b(i)=\frac{1}{|A|} \sum_{j \in C} d(i, j) \\
s(i)=\frac{b(i)-a(i)}{\operatorname{Max}(a(i), b(i))}
\end{gathered}
$$

Pada Persamaan 4 dan Persamaan 5 akan sangat dipengaruhi oleh jarak objek $i$ ke $j$ yang di tampung dalam variabel $\mathrm{d}(i, j)$, jumlah objek dikelompok $\mathrm{A}(A)$ dan jumlah objek dikelompok $\mathrm{C}(C)$. Persamaan 6 digunakan untuk menghitung nilai silhouette coefficient yang dipengaruhi oleh Persamaan 4 sebagai rumus untuk menghitung jarak objek dalam 1 kelompok disimbolkan dengan a $(i)$ dan dipengaruhi juga oleh Persamaan 5 yang digunakan untuk menghitung jarak objek di antara objek di kelompok lainnya disimbolkan dengan $\mathrm{b}(i)$.

Setelah didapatkan kualitas pengelompokan yang berkarakteristik maka selanjutnya analisis pemodelan data dilakukan dengan pengenalan pola-pola baru hasil pengelompokan untuk mendapatkan pengetahuan baru. Kesimpulan hasil memberikan jawaban kualitas karakteristik pada pengelompokan algoritma K-Means dan informasi pengetahuan baru dari pola-pola baru data mining capaian tengah semester genap 2020/2021 peserta didik kelas X Usaha Perjalanan Wisata 1 di SMK Negeri 4 Yogyakarta.

\section{Hasil dan Pembahasan}

Hasil preprocessing (pemilihan field, pembersihan data yang tidak terpakai, pengecekan konsistensi data) dan transformasi data berupa nilai rerata permata pelajaran. Format hasil preprocessing

\begin{tabular}{|c|c|c|c|c|c|c|c|c|c|c|c|c|}
\hline$\stackrel{8}{z}$ & Nama & 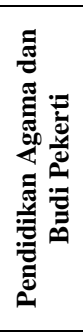 & $\vdots$ & 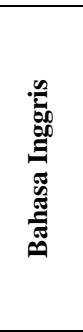 & 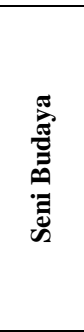 & 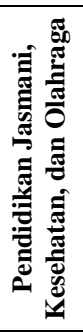 & 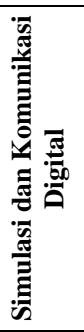 & 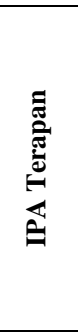 & 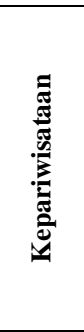 & 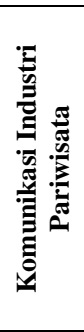 & $\vdots$ & 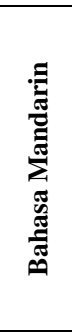 \\
\hline & & 1 & $\ldots$ & 6 & 7 & 8 & 9 & 10 & 11 & 12 & $\ldots$ & 16 \\
\hline 1 & $\begin{array}{l}\text { ADISTIA INDAYU } \\
\text { PUTRI }\end{array}$ & 81,65 &.. & 84,50 & 82,96 & 80,75 & 88,00 & 85,00 & 83,50 & 84,14 & $\ldots$ & 87,50 \\
\hline 2 & $\begin{array}{l}\text { AHMAD NANDITO } \\
\text { KUSMEIANTO }\end{array}$ & 80,74 &.. & 82,00 & 87,09 & 80,00 & 83,50 & 82,50 & 75,50 & 80,34 & $\cdots$ & 85,00 \\
\hline 3 & $\begin{array}{l}\text { ANNISA NUR } \\
\text { KHOLIFAH }\end{array}$ & 84,73 &.. & 89,50 & 85,68 & 82,75 & 87,50 & 83,50 & 83,17 & 86,89 & $\cdots$ & 90,00 \\
\hline 4 & $\begin{array}{l}\text { ANNISA RISQI } \\
\text { BAROQAH }\end{array}$ & 83,08 &.. & 88,50 & 85,56 & 80,00 & 87,00 & 85,00 & 78,50 & 85,72 & $\ldots$ & 83,00 \\
\hline 5 & ASTUTI EKA SARI & 82,13 & .. & 83,00 & 93,56 & 80,00 & 85,00 & 85,50 & 77,17 & 82,78 & $\ldots$ & 86,00 \\
\hline$\ldots$ & $\ldots$ & $\ldots$ & $\ldots$ & $\ldots$ & $\ldots$ & $\ldots$ & $\ldots$ & $\ldots$ & $\ldots$ & $\ldots$ & $\ldots$ & $\ldots$ \\
\hline 35 & $\begin{array}{l}\text { ZAKI RAIHAN } \\
\text { DHAWI }\end{array}$ & 77,40 & $\ldots$ & 79,50 & 79,89 & 80,00 & 79,50 & 77,50 & 75,00 & 75,00 & $\ldots$ & 81,50 \\
\hline
\end{tabular}
dan transformasi data terlihat pada Tabel 1.

Tabel 1. Hasil preprocessing dan transformasi.

Pada awalnya, data capaian tengah semester peserta didik terdiri dari 36 peserta didik, 16 mata pelajaran, nilai pengetahuan dan nilai keterampilan. Preprocessing telah membersihkan 1 peserta didik 
yang tidak memiliki nilai lengkap dikarenakan pindah sekolah. Preprocessing menghasilkan sejumlah 35 nilai rerata capaian tengah semester peserta didik dengan masing-masing peserta didik memiliki 1 nilai rerata pada masing-masing mata pelajaran.

\subsection{Clustering Algoritma K-Mean Model Pembelajaran}

Pengodean dilakukan dalam proses data mining, seperti kelompok pembelajaran jarak jauh dikodekan angka 0 dan kelompok PTMT dikodekan angka 1. Proses pengelompokan membutuhkan datadata penentu yang terdiri dari nilai delta. Delta ditentukan pengguna dengan nilai kesepakatan 0,10. Kelas adalah kelompok yang menentukan jumlah kelompok yang akan dibentuk, dibutuhkan 2 jenis pengelompokan PTMT dan PJJ. Max adalah nilai tertinggi yang diperoleh peserta didik pada mata pelajaran yang akan dilakukan pengelompokan, pada contoh mata pelajaran PAI nilai tertinggi yang didapatkan peserta didik adalah 87,10. Min adalah nilai terendah yang diperoleh peserta didik pada mata pelajaran yang akan dilakukan pengelompokan, pada contoh mata pelajaran PAI nilai terendah yang didapatkan peserta didik adalah 75,00. Toleransi error didapatkan dari nilai maksimal dikurangi nilai minimal dikalikan nilai delta. Nilai centroid kelompok $1\left(C_{l}\right)$ dan centroid kelompok $2\left(C_{2}\right)$ dihitung dengan menggunakan rumus pada Persamaan 1 yang telah dituliskan pada bagian metode penelitian. Data penentu pada proses pengelompokan pada mata pelajaran PAI diuraikan sebagai berikut :

$\begin{array}{lll}\text { Delta } & = & 0,10 \\ \text { Kelas }(n) & = & \mathrm{PTMT} / \mathrm{PJJ} \\ \text { Max } & = & 87,10 \\ \text { Min } & = & 75,00 \\ n & = & 2 \\ \text { Toleransi Error } & = & 1,21 \\ C_{1} & = & 78,03 \\ C_{2} & = & 84,075\end{array}$

Tahapan perhitungan jarak objek dilakukan dengan menerapkan Persamaan 2 untuk mendapatkan hasil yang dipetakan oleh model pembelajaran di mata pelajaran pendidikan agama. Hasil perhitungan jarak terlihat pada Tabel 2 sebagai berikut :

Tabel 2. Hasil clustering model belajar.

\begin{tabular}{|c|c|c|c|c|c|c|c|c|}
\hline \multirow{3}{*}{ No } & \multirow{3}{*}{ Siswa } & \multicolumn{7}{|c|}{ Muatan Nasional } \\
\hline & & \multicolumn{7}{|c|}{ Pendidikan Agama dan Budi Pekerti } \\
\hline & & & 78,03 & 84,08 & I & 79,63 & 82,80 & II \\
\hline 1 & ADISTIA INDAYU PUTRI & 81,65 & 3,63 & 2,42 & 0 & 2,02 & 1,15 & 0 \\
\hline 2 & AHMAD NANDITO KUSMEIANTO & 80,74 & 2,71 & 3,33 & 1 & 1,11 & 2,06 & 1 \\
\hline 3 & ANNISA NUR KHOLIFAH & 84,73 & 6,70 & 0,65 & 0 & 5,09 & 1,92 & 0 \\
\hline 4 & ANNISA RISQI BAROQAH & 83,08 & 5,05 & 1,00 & 0 & 3,44 & 0,27 & 0 \\
\hline 5 & ASTUTI EKA SARI & 82,13 & 4,10 & 1,95 & 0 & 2,49 & 0,68 & 0 \\
\hline 6 & AURELLIA HAPPY NUR RAHMAWATI & 82,92 & 4,89 & 1,16 & 0 & 3,28 & 0,11 & 0 \\
\hline 7 & BERLIANA OKTAVININDIA & 79,70 & 1,68 & 4,37 & 1 & 0,07 & 3,10 & 1 \\
\hline 8 & CANDIDA FIDELIA NURENITA & 83,95 & 5,93 & 0,12 & 0 & 4,32 & 1,15 & 0 \\
\hline 9 & CANDRITA SEPTANIA PUTRI MALIKA & 81,69 & 3,66 & 2,38 & 0 & 2,06 & 1,11 & 0 \\
\hline 10 & CEZARA VANIA DEVITA PUTRI & 82,19 & 4,16 & 1,88 & 0 & 2,56 & 0,61 & 0 \\
\hline 11 & DAMA KRISHNA DARMAKARYADIKA & 80,18 & 2,15 & 3,90 & 1 & 0,54 & 2,63 & 1 \\
\hline 12 & DHANIA ESHA AZ ZAHRA & 75,00 & 3,03 & 9,07 & 1 & 4,63 & 7,80 & 1 \\
\hline 13 & DHINDA NUR RIZKI ANDINI & 82,02 & 3,99 & 2,06 & 0 & 2,38 & 0,79 & 0 \\
\hline 14 & HELSA ILLONA PUTRI ARDANI & 78,98 & 0,95 & 5,10 & 1 & 0,66 & 3,83 & 1 \\
\hline 15 & INAS SYABRINA QINANTI & 81,78 & 3,75 & 2,30 & 0 & 2,14 & 1,03 & 0 \\
\hline 16 & MEUTHIA MURTI RAHAYU & 80,19 & 2,16 & 3,88 & 1 & 0,56 & 2,61 & 1 \\
\hline 17 & MUHAMMAD FAIZ MAULANA PUTRA HARSIT & 82,72 & 4,69 & 1,36 & 0 & 3,08 & 0,09 & 0 \\
\hline 18 & MUHAMMAD SAHAL DZULKAISI & 80,20 & 2,18 & 3,87 & 1 & 0,57 & 2,60 & 1 \\
\hline 20 & NANDA AULIYA RISKA WULANDARI & 80,73 & 2,70 & 3,35 & 1 & 1,09 & 2,08 & 1 \\
\hline 21 & NAUFAL IQBAL AMAR TRISNA & 82,93 & 4,90 & 1,15 & 0 & 3,29 & 0,12 & 0 \\
\hline 22 & NAZA SETIA AJI & 79,80 & 1,77 & 4,27 & 1 & 0,17 & 3,00 & 1 \\
\hline 23 & NUR ISMI RAHMANIA & 81,94 & 3,91 & 2,13 & 0 & 2,31 & 0,86 & 0 \\
\hline 24 & NURAINI NIA AGUSTINA & 83,80 & 5,77 & 0,27 & 0 & 4,17 & 1,00 & 0 \\
\hline 25 & PRATIWI PUTRI NURMANINGSIH & 81,28 & 3,25 & 2,80 & 0 & 1,64 & 1,53 & 0 \\
\hline 26 & Q'NANTI KATYA SYIFA' PRIYONO & 80,85 & 2,82 & 3,22 & 1 & 1,22 & 1,95 & 1 \\
\hline 27 & RADEN RORO RADISYA PRATIWI ARDANANTI & 79,90 & 1,88 & 4,17 & 1 & 0,27 & 2,90 & 1 \\
\hline 28 & RAHMA DZULFANI UKY & 79,74 & 1,71 & 4,33 & 1 & 0,11 & 3,06 & 1 \\
\hline
\end{tabular}




\begin{tabular}{|c|c|c|c|c|c|c|c|c|}
\hline \multirow{3}{*}{ No } & \multirow{3}{*}{ Siswa } & \multicolumn{7}{|c|}{ Muatan Nasional } \\
\hline & & \multicolumn{7}{|c|}{ Pendidikan Agama dan Budi Pekerti } \\
\hline & & & 78,03 & 84,08 & I & 79,63 & 82,80 & II \\
\hline 29 & RINASARI SIMANJUNTAK & 80,95 & 2,93 & 3,12 & 1 & 1,32 & 1,85 & 1 \\
\hline 30 & SHAFIRA RAHMA DINI & 87,10 & 9,07 & 3,03 & 0 & 7,47 & 4,30 & 0 \\
\hline 31 & TITI SARI ARUM CENDANI & 80,44 & 2,41 & 3,63 & 1 & 0,81 & 2,36 & 1 \\
\hline 32 & TRIA RACHMADANI & 79,33 & 1,30 & 4,75 & 1 & 0,31 & 3,48 & 1 \\
\hline 33 & VERA RIZMA FADILA & 82,87 & 4,84 & 1,21 & 0 & 3,23 & 0,06 & 0 \\
\hline 34 & YULIANSYAH ICHWAN PRADIPTA & 82,02 & 3,99 & 2,06 & 0 & 2,38 & 0,79 & 0 \\
\hline 35 & YUNIA ADITYA & 82,52 & 4,49 & 1,56 & 0 & 2,88 & 0,29 & 0 \\
\hline 36 & ZAKI RAIHAN DHAWI & 77,40 & 0,63 & 6,67 & 1 & 2,23 & 5,40 & 1 \\
\hline
\end{tabular}

Pada Tabel 2 terlihat bahwa terjadi iterasi sebanyak 2 kali. Tabel 3 memperlihatkan proses iterasi yang terjadi, di mana pada iterasi ke-1 rerata-centroid yang dihasilkan sebesar 2,88 lebih besar dari nilai toleransi errornya yaitu 1,21. Iterasi ke 2 telah memenuhi dengan nilai rerata-centroid 0 (nol) dan centroid tidak mengalami perubahan dengan $\mathrm{C} 1=79,63$ dan $\mathrm{C} 2=82,80$ sehingga proses berakhir pada iterasi ke 2 ini.

Tabel 3. Rerata, centroid, rerata centroid pada iterasi 1 dan 2 clustering model pembelajaran.

\begin{tabular}{|c|c|c|c|c|c|c|}
\hline Kelas & Rerata & Centroid & $\mid$ Rerata-Centroid $\mid$ & Rerata & Centroid & $\mid$ Rerata-Centroid $\mid$ \\
\hline & \multicolumn{3}{|c|}{ ITERASI 1} & \multicolumn{3}{|c|}{ ITERASI 2} \\
\hline 1 (PTMT) & 79,63 & 78,03 & 1,61 & 79,63 & 79,63 & 0,00 \\
\hline \multirow{2}{*}{ O (ONLINE) } & 82,80 & 84,08 & 1,27 & 82,80 & 82,80 & 0,00 \\
\hline & TOTAL & & 2,88 & & & 0,00 \\
\hline \multicolumn{4}{|c|}{$\begin{array}{c}\text { Oleh karena TOLERANSI } \text { error }=1,21 \text { maka 2,88>1,21 sehingga } \\
\text { lakukan ITERASI Kedua }\end{array}$} & \multicolumn{3}{|c|}{ Hasil iterasi 2 sudah memenuhi } \\
\hline
\end{tabular}

Proses pengelompokan diberlakukan kepada seluruh mata pelajaran untuk mendapatkan rekap hasil pengelompokan model pembelajaran. Peserta didik yang mengalami kendala dalam beradaptasi belajar dimasa pandemi COVID-19 ini disajikan pada Tabel 4 kelompok PTMT. Persentase model pembelajaran pada tiap mata pelajaran menunjukkan jumlah peserta didik yang terkendala dalam proses belajar dibandingkan jumlah peserta didik yang ada. Persentase dapat dijadikan masukan kepada pengampu mata pelajaran untuk melakukan diagnosa terhadap proses pembelajaran yang telah dilakukan sehingga mencapai kualitas penyampaian materi yang dapat lebih berkualitas.

Tabel 4. Rekap hasil clustering model pembelajaran.

\begin{tabular}{|c|c|c|c|c|c|c|c|c|c|c|c|c|c|c|c|}
\hline 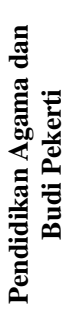 & 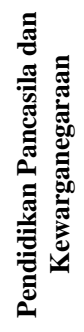 & 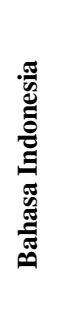 & 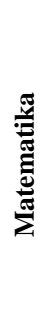 & 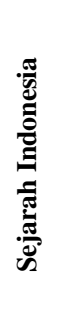 & 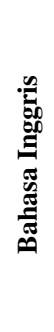 & 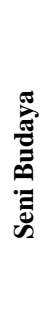 & 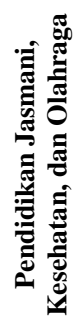 & 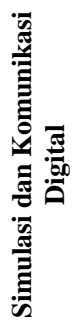 & 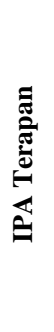 & 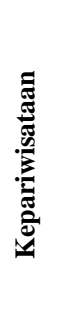 & 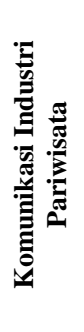 & 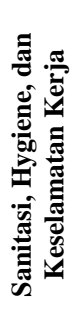 & 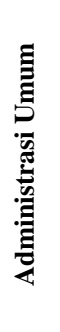 & 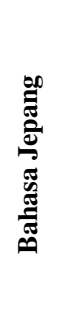 & 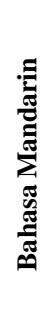 \\
\hline 16 & 29 & 12 & 16 & 4 & 15 & 13 & 26 & 7 & 11 & 22 & 10 & 25 & 31 & 8 & 11 \\
\hline 46 & 80 & 34 & 43 & 11 & 40 & 34 & 71 & 20 & 31 & 63 & 29 & 69 & 86 & 23 & 31 \\
\hline$\%$ & $\%$ & $\%$ & $\%$ & $\%$ & $\%$ & $\%$ & $\%$ & $\%$ & $\%$ & $\%$ & $\%$ & $\%$ & $\%$ & $\%$ & $\%$ \\
\hline
\end{tabular}

\subsection{Analisis Kualitas Karakteristik Clustering}

Pengukuran kualitas hasil pengelompokan akan dilakukan menggunakan metode silhouette coefficient dengan cara menghitung jarak antar dokumen menggunakan rumus euclidean distance. Hasil pengukuran kualitas pengelompokan terlihat pada Tabel 5. Model pembelajaran dari masing-masing peserta didik yang telah dihasilkan dari proses pengelompokan akan menjadi penentu pada perhitungan jarak di antara dokumen. Proses menghitung jarak objek di dalam satu kelompok yang disimbolkan a(i) dihitung menggunakan rumus pada Persamaan 4, sedangkan Persamaan 5 digunakan sebagai rumus untuk menghitung jarak objek di antara objek di kelompok lainnya disimbolkan dengan b(i). Nilai a(i) dan b(i) dari masing-masing peserta didik diproses dengan rumus pada Persamaan 6 untuk menghasilkan nilai Si dari masing-masing peserta didik. Nilai Si seluruh peserta didik dilakukan proses rerata seperti terlihat pada Tabel 5 menunjukkan nilai Si dari proses pengelompokan model pembelajaran sebesar 0,8313. Perhitungan 
manual dari proses pengelompokan sampai dengan perhitungan kualitas pengelompokan terdapat dalam 1 file spreadsheet yang dapat di-download di tautan http://tiny.cc/olah_KMeans.

Tabel 5. Hasil pengukuran kualitas karakteristik clustering model belajar.

\begin{tabular}{|c|c|c|c|c|c|c|}
\hline \multirow{2}{*}{ No } & \multirow{2}{*}{ Siswa } & \multicolumn{2}{|c|}{ Hasil Clustering } & \multirow[b]{2}{*}{$\mathrm{a}(\mathrm{i})$} & \multirow[b]{2}{*}{ b(i) } & \multirow{2}{*}{ S(i) } \\
\hline & & Nilai & Model & & & \\
\hline 1 & ADISTIA INDAYU PUTRI & 82,92 & 0 & 1,07 & 9,9 & 0,89 \\
\hline 2 & AHMAD NANDITO KUSMEIANTO & 75,00 & 1 & 8,89 & 2,13 & 0,76 \\
\hline 3 & ANNISA NUR KHOLIFAH & 84,25 & 0 & 0,83 & 11,2 & 0,93 \\
\hline 4 & ANNISA RISQI BAROQAH & 75,00 & 1 & 8,89 & 2,13 & 0,76 \\
\hline 5 & ASTUTI EKA SARI & 83,23 & 0 & 0,9 & 10,2 & 0,91 \\
\hline 6 & AURELLIA HAPPY NUR RAHMAWATI & 83,05 & 0 & 0,99 & 10 & 0,90 \\
\hline 7 & BERLIANA OKTAVININDIA & 75,00 & 1 & 8,89 & 2,13 & 0,76 \\
\hline 8 & CANDIDA FIDELIA NURENITA & 84,10 & 0 & 0,8 & 11,1 & 0,93 \\
\hline 9 & CANDRITA SEPTANIA PUTRI MALIKA & 85,02 & 0 & 1,27 & 12 & 0,89 \\
\hline 10 & CEZARA VANIA DEVITA PUTRI & 83,27 & 0 & 0,88 & 10,2 & 0,91 \\
\hline 11 & DAMA KRISHNA DARMAKARYADIKA & 83,30 & 0 & 0,88 & 10,3 & 0,91 \\
\hline 12 & DHANIA ESHA AZ ZAHRA & 75,00 & 1 & 8,89 & 2,13 & 0,76 \\
\hline 13 & DHINDA NUR RIZKI ANDINI & 85,00 & 0 & 1,25 & 12 & 0,90 \\
\hline 14 & HELSA ILLONA PUTRI ARDANI & 75,00 & 1 & 8,89 & 2,13 & 0,76 \\
\hline 15 & INAS SYABRINA QINANTI & 84,16 & 0 & 0,81 & 11,1 & 0,93 \\
\hline 16 & MEUTHIA MURTI RAHAYU & 82,18 & 0 & 1,71 & 9,16 & 0,81 \\
\hline 17 & MUHAMMAD FAIZ MAULANA PUTRA HARSIT & 84,37 & 0 & 0,87 & 11,3 & 0,92 \\
\hline 18 & MUHAMMAD SAHAL DZULKAISI & 83,37 & 0 & 0,86 & 10,3 & 0,92 \\
\hline 20 & NANDA AULIYA RISKA WULANDARI & 84,64 & 0 & 1,02 & 11,6 & 0,91 \\
\hline 21 & NAUFAL IQBAL AMAR TRISNA & 75,00 & 1 & 8,89 & 2,13 & 0,76 \\
\hline 22 & NAZA SETIA AJI & 48,33 & 1 & 35,6 & 24,7 & 0,31 \\
\hline 23 & NUR ISMI RAHMANIA & 84,17 & 0 & 0,81 & 11,1 & 0,93 \\
\hline 24 & NURAINI NIA AGUSTINA & 85,34 & 0 & 1,53 & 12,3 & 0,88 \\
\hline 25 & PRATIWI PUTRI NURMANINGSIH & 82,89 & 0 & 1,1 & 9,86 & 0,89 \\
\hline 26 & Q'NANTI KATYA SYIFA' PRIYONO & 83,13 & 0 & 0,94 & 10,1 & 0,91 \\
\hline 27 & RADEN RORO RADISYA PRATIWI ARDANANTI & 75,00 & 1 & 8,89 & 2,13 & 0,76 \\
\hline 28 & RAHMA DZULFANI UKY & 75,00 & 1 & 8,89 & 2,13 & 0,76 \\
\hline 29 & RINASARI SIMANJUNTAK & 75,00 & 1 & 8,89 & 2,13 & 0,76 \\
\hline 30 & SHAFIRA RAHMA DINI & 84,39 & 0 & 0,88 & 11,4 & 0,92 \\
\hline 31 & TITI SARI ARUM CENDANI & 75,00 & 1 & 8,89 & 2,13 & 0,76 \\
\hline 32 & TRIA RACHMADANI & 76,00 & 1 & 7,89 & 2,97 & 0,62 \\
\hline 33 & VERA RIZMA FADILA & 86,20 & 0 & 2,3 & 13,2 & 0,82 \\
\hline 34 & YULIANSYAH ICHWAN PRADIPTA & 82,57 & 0 & 1,35 & 9,55 & 0,86 \\
\hline 35 & YUNIA ADITYA & 84,04 & 0 & 0,8 & 11 & 0,93 \\
\hline 36 & ZAKI RAIHAN DHAWI & 75,00 & 1 & 8,89 & 2,13 & 0,76 \\
\hline \multicolumn{2}{|c|}{ Nilai Silhouette Coefficient } & & & & & $\mathbf{0 , 8 3 1 3}$ \\
\hline
\end{tabular}

Nilai silhouette coefficient yang dihasilkan dari pengukuran yang telah dilakukan menghasilkan nilai 0,8313 yang berarti mendekati 1 dikategorikan sebagai pengelompokan dengan kualitas karakteristik yang lebih baik yaitu jarak di antara objek dalam satu kelompok berdekatan (kelompok menunjukkan karakteristik objek yang sama) dan jarak objek di antara kelompok berpotensi kecil berada pada lebih dari satu kelompok (struktur baik). Pengertian tersebut jika dikaitkan dengan hasil pengelompokan model pembelajaran maka peserta didik yang berada dalam satu kelompok model pembelajaran memiliki kedekatan nilai yang hampir sama dan untuk peserta didik yang berada di kelompok model pembelajaran yang berbeda akan menunjukkan perbedaan nilai yang signifikan.

\subsubsection{Pengenalan Pola-Pola Baru Hasil Clustering Model Pembelajaran}

Proses pengenalan pola-pola baru hasil pengelompokan model pembelajaran berupa jumlah peserta didik kelompok PTMT sebagai kelompok yang terkendala dalam beradaptasi di pelaksanaan proses pembelajaran masa pandemi COVID-19. Data tersebut selanjutnya dilakukan proses pengelompokan untuk menghasilkan informasi yang dapat digunakan sebagai masukan kepada pengampu mata pelajaran untuk melakukan diagnosa terhadap proses pembelajaran yang telah dilakukan sehingga dapat mencapai kualitas penyampaian materi yang lebih meningkat. Tabel 6 menampilkan jumlah peserta didik yang terkendala pada masing-masing mata pelajaran dan menunjukkan daya serap peserta didik dari masing-masing mata pelajaran. Data mining yang dilakukan menghasilkan pengetahuan baru berupa tingkat daya serap peserta didik terhadap mata pelajaran yang terbagi menjadi 4 kelompok daya serap yaitu daya serap tinggi, daya serap standar, daya serap rendah dan daya serap kurang.

Jurnal Eksplora Informatika Vol. 11, No. 1, September 2021. 
Tabel 6. Pengetahuan baru hasil pengenalan pola baru.

\begin{tabular}{|c|c|c|c|c|c|c|c|}
\hline \multirow[b]{2}{*}{ NO } & \multirow[b]{2}{*}{ MAPEL } & \multirow{2}{*}{$\begin{array}{c}\text { JMH } \\
\text { Peserta } \\
\text { Didik } \\
\end{array}$} & K1 & $\mathbf{K 2}$ & K3 & K4 & \multirow{2}{*}{$\begin{array}{c}\text { Kelompok } \\
\text { Rumpun Mata } \\
\text { Pelajaran } \\
\end{array}$} \\
\hline & & & 7 & 14 & 21 & 28 & \\
\hline 1 & Pendidikan Agama dan Budi Pekerti & 16 & 9 & 2 & 5 & 12 & Daya Serap Standar \\
\hline 2 & Pendidikan Pancasila dan Kewarganegaraan & 29 & 22 & 15 & 8 & 1 & Daya Serap Kurang \\
\hline 3 & Bahasa Indonesia & 12 & 5 & 2 & 9 & 16 & Daya Serap Standar \\
\hline 4 & Matematika & 16 & 9 & 2 & 5 & 12 & Daya Serap Standar \\
\hline 5 & Sejarah Indonesia & 4 & 3 & 10 & 17 & 24 & Daya Serap Tinggi \\
\hline 6 & Bahasa Inggris & 15 & 8 & 1 & 6 & 13 & Daya Serap Standar \\
\hline 7 & Seni Budaya & 13 & 6 & 1 & 8 & 15 & Daya Serap Standar \\
\hline 8 & Pendidikan Jasmani, Kesehatan, dan Olahraga & 26 & 19 & 12 & 5 & 2 & Daya Serap Kurang \\
\hline 9 & Simulasi dan Komunikasi Digital & 7 & 0 & 7 & 14 & 21 & Daya Serap Tinggi \\
\hline 10 & IPA Terapan & 11 & 4 & 3 & 10 & 17 & Daya Serap Standar \\
\hline 11 & Kepariwisataan & 22 & 15 & 8 & 1 & 6 & Daya Serap Rendah \\
\hline 12 & Komunikasi Industri Pariwisata & 10 & 3 & 4 & 11 & 18 & Daya Serap Tinggi \\
\hline 13 & Sanitasi, Hygiene, dan Keselamatan Kerja & 25 & 18 & 11 & 4 & 3 & Daya Serap Kurang \\
\hline 14 & Administrasi Umum & 31 & 24 & 17 & 10 & 3 & Daya Serap Kurang \\
\hline 15 & Bahasa Jepang & 8 & 1 & 6 & 13 & 20 & Daya Serap Tinggi \\
\hline 16 & Bahasa Mandarin & 11 & 4 & 3 & 10 & 17 & Daya Serap Standar \\
\hline
\end{tabular}

\section{Kesimpulan}

Kebutuhan pengelompokan model pembelajaran pada nilai capaian hasil belajar peserta didik selama tengah semester kelas X Usaha Perjalanan Wisata 1 di SMK Negeri 4 Yogyakarta yang terukur kualitas karakteristiknya dengan pembuktian eksperimen menggunakan algoritma K-Means. Hasil pengukuran dengan metode sihouette coefficient telah terbukti bahwa kualitas karakteristik yang lebih baik yaitu jarak di antara objek dalam satu kelompok berdekatan (kelompok menunjukkan karakteristik objek yang sama) dan jarak objek di antara kelompok berpotensi kecil berada pada lebih dari satu kelompok (struktur baik). Implikasi hasil pengelompokan model pembelajaran adalah peserta didik yang berada dalam satu kelompok model pembelajaran memiliki kedekatan nilai yang hampir sama dan untuk peserta didik yang berada di kelompok model pembelajaran yang berbeda akan menunjukkan perbedaan nilai yang signifikan. Pengenalan pola-pola baru hasil pengelompokan model pembelajaran menghasilkan pengetahuan baru berupa jumlah peserta didik yang terkendala pada masing-masing mata pelajaran dan menunjukkan daya serap peserta didik dari masing-masing mata pelajaran yang terbagi menjadi 4 kelompok daya serap yaitu daya serap tinggi, daya serap standar, daya serap rendah dan daya serap kurang.

Hasil yang telah didapatkan perlu dikembangkan untuk menghasilkan perencanaan pembelajaran tatap muka terbatas sesuai dengan sumber daya yang dimiliki dan persyaratan pelaksanaan PTMT pasca vaksinasi COVID-19. Untuk dapat memberikan perencanaan PTMT secara otomatis maka dibutuhkan :

1. Pengelompokan diberlakukan kepada seluruh kelas yang ada di SMK Negeri 4 Yogyakarta

2. Mendata durasi waktu, sarana dan prasarana yang akan diberlakukan pada PTMT Pasca Vaksinasi COVID-19

3. Menghitung secara matematis kebutuhan penjadwalan, sarana dan prasarana tiap mata pelajaran yang akan diberlakukan PTMT Pasca Vaksinasi COVID-19.

\section{Daftar Pustaka}

[1] K. R. dan T. Kementerian Pendidikan, "Penyesuaian kebijakan pembelajaran di masa pandemi COVID-19," 2021.

[2] V. Julianto and J. Permadi, “Aplikasi pemilihan strategi promosi penerimaan mahasiswa baru politeknik negara tanah laut menggunakan metode k-means clustering," J. Ilm. Inform., vol. 2, no. 1, pp. 99-104, Jun. 2017, doi: 10.5281/JIMI.V1I2.37.

[3] S. Lesmana et al., "Penerapan k-means dalam efektivitas pembelajaran e-learning pada masa pandemi covid-19," Semin. Nas. Inform., vol. 2020, no. 1, pp. 100-110, Dec. 2020.

[4] K. D. R Sianipar et al., "Penerapan algoritma k-means dalam menentukan tingkat kepuasan pembelajaran online pada masa pandemi covid-19," J. Teknol. Inf., vol. 4, no. 1, pp. 101-105, Jun. 2020.

[5] N. Afni Syahpitri Damanik, M. Prodi Sistem Informasi, S. Royal, P. Sistem Informasi, and P. Manajemen Informasi, "Penerapan metode clustering dengan algoritma k-means tindak kejahatan pencurian di kabupaten asahan," J. Comput., vol. 1, no. 1, pp. 7-14, Feb. 2021.

[6] E. Sugiharti and A. Muslim, "On-line clustering of lecturers performance of computer science 
department of semarang state university using k-means algorithm,” J. Theor. Appl. Inf. Technol., vol. 10, no. 1, 2016.

[7] S. Dewi, S. Defit, and Y. Yunus, "Akurasi Pemetaan Kelompok Belajar Siswa Menuju Prestasi Menggunakan Metode K-Means (Studi Kasus SMP Pembangunan Laboratorium UNP),” J. Sistim Inf. dan Teknol., Sep. 2020, doi: 10.37034/jsisfotek.v3i1.98.

[8] A. Sani, "Penerapan metode k-means clustering pada perusahaan," J. Ilm. Progr. Pascasarj. Magister Ilmu Komput. STMIK Nusa Mandiri, pp. 1-7, 2018.

[9] T. Soni Madhulatha, "An overview on clustering methods," vol. 2, no. 4, pp. 719-725, 2012.

[10] R. Hidayati, A. Zubair, A. H. Pratama, and L. Indana, "Analisis Silhouette Coefficient pada 6 Perhitungan Jarak K-Means Clustering,” Techno.Com, vol. 20, no. 2, pp. 186-197, May 2021, doi: 10.33633/tc.v20i2.4556. 